\title{
The Effect of Local Microorganism (Mol) as Liquid Organic Fertilizer to the Growth of Ipomea reptans Poir
}

\author{
Meta Yuliana \\ Biology Study Program, Faculty of Science and Technology, Universitas Islam Negeri Raden \\ Fatah Palembang, Indonesia
}

*email: metayuliana_uin@radenfatah.ac.id

\begin{tabular}{|c|c|}
\hline Article Info & Abstract \\
\hline & This research aim to determine the effect of Mol of Chinese \\
\hline Key word: & cabbage and cabbage to the growth of Ipomoea reptans \\
\hline Mol & Poir. The methods used was Randomized Complete Design \\
\hline Chinese cabbage & consist of 4 treatments and 6 repetitions; P0: $0 \%$ Mol, P1: \\
\hline Cabbage & 5\% Mol, P2: 10\% Mol, and P3 15\% Mol. The Data were \\
\hline Ipomea reptans Poir & analyzed using Analysis of Variance (ANOVA) followed by \\
\hline Fertilizer & $\begin{array}{l}\text { Duncan Multiple Range Test for differences among } \\
\text { treatments. The observations on Mol consist of } p H \text {, }\end{array}$ \\
\hline Article history: & number of bacteria and number of fungi and the growth of \\
\hline Received: $27 / 11 / 2020$ & Ipomoea reptans Poir. The result showed that the \\
\hline Revised: 06/01/2021 & treatment P3 $15 \%$ Mol gives effect on number of leaves, \\
\hline Accepted: 09/01/2021 & $\begin{array}{l}\text { dry weight, shoot dry weight dan soil pH, but there's no } \\
\text { significant effect on height plant, wet weight, root dry } \\
\text { weight, ratio of shoot and root, also to number of bacteria, } \\
\text { number of fungi and pH of Mol. However, Mol of Chinese } \\
\text { cabbage and cabbage can be a fertilizer to growth of } \\
\text { Ipomoea reptans Poir. }\end{array}$ \\
\hline
\end{tabular}

Copyright $@ 2021$ The Author(s). All Right Reserved

\section{Introduction}

Anorganic fertilizer is one of the problems in agriculture. It can increase the growth of plants faster but is harmful for the environment. Chemical material in Anorganic fertilizer could be toxic for soil. It changes the structure of soil; reduces soil microbial abundance and soil properties. The result of this condition is the damage of soil permanently (Priambodo et al, 2019). The alternative solution to solve this problem is the application of organic fertilizer. Organic fertilizer made by the decomposing of natural material in earth such as cow manure, chicken manure and vegetable waste.
Widha et al (2018), said that organic fertilizer could increase the growth of plants such as Tomato. It affects the fruit $\mathrm{N}$ uptake and plant height of tomatoes. Purbajanti et, al (2019), also said that organic fertilizer has the similar effect on growth and physiology of peanut plants compared to NPK fertilizer. Meanwhile, Lin et al (2019), found that organic fertilizer can increase the amino acids content of tea, $\mathrm{pH}$ soil, lower level of heavy metal such $\mathrm{Cd}, \mathrm{Pb}$, and as in rhizosphere soils and increased microbial abundance in soil compared to chemical fertilizer.

Mol or Local Microorganism is one of the organic fertilizers. It is a fermented 
liquid as the product of organic material fermentation. According to Mursalim et al (2018), Mol has the effect in increasing Brassica juncea growth. It also has a significant result in increasing the growth of Solanum lycopersicum var. cerasiforme and Vigna sinensis L, (Widha $e t, a l, 2018$; Zulputra and Taufik Hidayat, 2018). Suwatanti and P Widiyaningrum (2017), said that the addition of Mol from vegetables in organic material composting can increase the compost quality better than EM4. In addition, Kusmanto et al (2019) said that the function of Mol is not only in increasing the plant growth but it can fix the biological, chemical and physical condition of soil.

Previous research has found that vegetable waste can be used as a substrate for Mol fermentation. The results showed that mixing vegetable waste had an effect on plant growth and productivity (Lestari et al, 2019; Qaderi et al, 2019). However, in this research, Mol was made by using the combination only of two vegetables waste (Chinese cabbage and cabbage) collected from The Jakabaring Traditional market in Palembang, South Sumatera. The purpose of this study was to determine the effect of the combination of Chinese cabbage and cabbage waste as a substrate for Mol fermentation and as fertilizer on the growth of Ipomea reptants poir.

\section{Materials and Methods}

This research used Randomized Complete Design consisting of 4 treatments and 6 repetitions; P0: 0\% Mol, P1: 5\% Mol, P2: 10\% Mol, and P3 15\% Mol. The observation parameters were Mol condition and effect of Mol to plant. The observations on Mol consist of $\mathrm{pH}$, number of bacteria and number of fungi. The Mol was observed at first and the fourth weeks of storage. The observation on bacteria and fungi in Mol used serial dilution and Total Plate Count Methods.
The observations on plants included height plants, number of leaves, wet weight, dry weight, shoot dry weight, root dry weight, ratio of root and shoot, and Soil pH. The Data were analyzed used Analysis of Variance (ANOVA) followed by Duncan Multiple Range Test for differences among treatments means

\section{Mol Preparation}

$2 \mathrm{~kg}$ waste of Chinese cabbage and 2 $\mathrm{kg}$ waste of cabbage were blended. Mix them in ratio 1:1 and put in a jar. 1 liter of rice laundry water and 200 gram of salt were added to the mix. The jar was closed and fermented for 3 weeks (Suswandi and Suharto, 2011).

\section{Mol Storing}

After 3 weeks fermentation, the jar was opened. The fermented product was filtered to separate Mol and substrate. The Mol was moved to a bottle that had the lid closed. Bottle's lid was perforated to insert a small hose that was connected to another bottle filled with water (Suswandi and Suharto, 2011).

\section{Plant Preparation}

Seeds of Ipomea reptans Poir were germinated for 1 week. After 1 week, the young plants were moved to a polybag containing Podzolic Soil. Mol was given as liquid organic fertilizer every day in the morning and afternoon. The plant was harvested after 14 days of growth to be observed.

\section{Results and Discussion \\ Result \\ pH and Total Number of Microorganism in Mol}

The data showed that there was no statistically significant increase, but there was an increase in the number of bacteria and number of fungi in Mol from the $1^{\text {st }}$ week of storage to $4^{\text {th }}$ weeks of storage, while the $\mathrm{pH}$ of Mol was decreased. The average $\mathrm{pH}$ of Mol in the first week after fermentation was 4 then decreased to $\mathrm{pH}$ 
3 in the forth weeks. The number of fungi increased more than bacteria after 4 weeks of storage (Table 1).

\section{The Growth of Ipomea reptans Poir}

The Anova $(0,05 \%)$ test showed that there are no statistically significant differences between treatments to the height of plants. However, the height of the plant was increasing during the treatment with Mol. The early height of plants was $5 \mathrm{~cm}$, then increasing to average $10 \mathrm{~cm}$ in 4 weeks at each treatment. The highest height of the plant was P2. On the other hand, the number of leaves of plants has statistically significant differences between treatment $\mathrm{P} 3$ with $\mathrm{P} 0, \mathrm{P} 1$, and $\mathrm{P} 3$. The number of leaves also increased in 4 weeks. The early average number of leaves was 4 leaves then increased to average 10 leaves. The highest average number of leaves was P3 (Table 2).

The Anova $(0,05 \%)$ test of wet weight, root dry weight and ratio of shoot and root showed no statistically significant differences, while dry weight, shoot dry weight and Soil $\mathrm{pH}$ were significant. P3 treatment has the highest average of wet weight, dry weight, shoot dry weight and ratio of shoot and root. Yet, the averages of root dry weight are similar in all treatments. The $\mathrm{pH}$ condition was decreased to acidity condition as effect of Mol treatment. The highest acidity average number of Soil $\mathrm{pH}$ was at P3 treatment (Table 3).

Table 1. The Number of bacteria, fungi and $\mathrm{pH}$ of Mol during storage

\begin{tabular}{cccccccc}
\hline & & \multicolumn{4}{c}{ Beginning } & \multicolumn{3}{c}{ End } \\
\cline { 3 - 8 } Treatment & Concentration & $\mathbf{p H}$ & $\begin{array}{c}\text { Total of } \\
\text { Bacteria } \\
\left(\mathbf{L o g ~ 1 0}^{7}\right)\end{array}$ & $\begin{array}{c}\text { Total of } \\
\text { Fungi } \\
(\mathbf{L o g ~ 1 0})\end{array}$ & $\mathbf{p H}$ & $\begin{array}{c}\text { Total of } \\
\text { Bacteria } \\
\left(\log \mathbf{~ 1 0}^{7}\right)\end{array}$ & $\begin{array}{c}\text { Total of } \\
\text { Fungi } \\
\left(\mathbf{L o g} \mathbf{1 0}^{7}\right)\end{array}$ \\
\hline P0 & $0 \%$ & - & - & - & - & - & - \\
P1 & $5 \%$ & 4,14 & 8.67 & 8.87 & 3,71 & 8.94 & 9.44 \\
P2 & $10 \%$ & 4,16 & 8.51 & 8.83 & 3,81 & 8.90 & 9.27 \\
P3 & $15 \%$ & 4,18 & 8.20 & 8.56 & 3,91 & 8.49 & 9.23 \\
\hline
\end{tabular}

Table 2. The Height plant and number of leaves of Ipomea reptans Poir

\begin{tabular}{cccccc}
\hline \multirow{2}{*}{ Treatment } & \multirow{2}{*}{ Concentration } & \multicolumn{2}{c}{ Height $(\mathbf{c m})$} & \multicolumn{2}{c}{ Number of Leaves (Strands) } \\
\cline { 3 - 6 } & & Before & After & Before & After \\
\hline P0 & $0 \%$ & 5 & 10.17 & 4 & $9^{\mathrm{a}}$ \\
P1 & $5 \%$ & 5 & 10.25 & 4 & $10^{\mathrm{ab}}$ \\
P2 & $10 \%$ & 5 & 11.67 & 4 & $10^{\mathrm{abc}}$ \\
P3 & $15 \%$ & 5 & 10.25 & 4 & $11^{\mathrm{bc}}$ \\
\hline
\end{tabular}

* The number followed by different letter indicate statistically significant

Table 3. The Weight Parameter, Ratio Shoot and Root, and Soil pH

\begin{tabular}{cccccccc}
\hline Treatment & Concentration & $\begin{array}{c}\text { Wet } \\
\text { Weight } \\
\text { (gram) }\end{array}$ & $\begin{array}{c}\text { Dry } \\
\text { Weight } \\
\text { (gram) }\end{array}$ & $\begin{array}{c}\text { Shoot Dry } \\
\text { Weight } \\
\text { (gram) }\end{array}$ & $\begin{array}{c}\text { Root Dry } \\
\text { Weight } \\
\text { (gram) }\end{array}$ & $\begin{array}{c}\text { Ratio } \\
\text { Shoot } \\
\text { and Root } \\
(\%)\end{array}$ & $\begin{array}{c}\text { Soil } \\
\text { pH }\end{array}$ \\
\hline P0 & $0 \%$ & 1.50 & $0.38^{\mathrm{a}}$ & $0.25^{\mathrm{a}}$ & 0.13 & 2.17 & $6.62^{\mathrm{a}}$ \\
P1 & $5 \%$ & 1.38 & $0.35^{\mathrm{ab}}$ & $0.25^{\mathrm{a}}$ & 0.10 & 2.50 & $5.83^{\mathrm{a}}$ \\
P2 & $10 \%$ & 1.52 & $0.55^{\mathrm{abc}}$ & $0.42^{\mathrm{b}}$ & 0.13 & 3.33 & $5.22^{\mathrm{b}}$ \\
P3 & $15 \%$ & 1.78 & $0.63^{\mathrm{cd}}$ & $0.50^{\mathrm{bc}}$ & 0.13 & 4.17 & $5.05^{\mathrm{c}}$ \\
\hline
\end{tabular}

* The number followed by different letter indicate statistically significant 


\section{Discussion}

The fermentation process by microorganisms such as bacteria and fungi cause the change in $\mathrm{pH}$. Microorganisms used the vegetables as substrate in the fermentation process. Widjajanto et, al (2017) found that the domination of bacteria population in vegetables Mol was Lactobacillus sp. These bacteria are a group of Lactic Acid Bacteria and most found in the fermentation process. Yuliana et al (2019) said that the decreasing of $\mathrm{pH}$ in the fermentation process as a result of activity of Lactic Acid Bacteria. It used substrate to produce organic acid and their growth. Organic acid production causes the acidity condition on Mol. However, the bacteria activity also changes the nutritional value on Mol. It can increase the $\mathrm{C} / \mathrm{N}$ ratio on $\mathrm{Mol}$ (Widjajanto et, al, 2017). Fungi also have a role in Mol condition. Firdaus et al (2014) found the increase of $\mathrm{C} / \mathrm{N}$ ratio during the Mol fermentation with Tempe yeast.

Fermentation process made Mol have potential as organic fertilizer for plants. The data of this study showed that addition of Mol (P0, P2, and P3) increased the dry weight and shoot dry weight of plant weightier compared to P0. These data state that Mol from Chinese cabbage and cabbage has effect in yield production of Ipomea reptans Poir as similar to the effect of Mol of Vegetables to another plant such as Cayenne pepper plant (Syafruddin et al, 2019).

This data similar to previous study that Mol from banana weevil also has effect in yield production of Ipomea reptans Poir (Jumriani et, al, 2017). In addition, Zulputra et, al (2018) found that Mol from mango has an effect in production of peas.

Yet, Mol from Chinese cabbage and cabbage did not affect the height of plant, wet weight, root dry weight and ratio of shoot and root of Ipomea reptans
Poir. However, the P3 gave the effect of the number of leaves. This condition is thought to be caused by several factors. The unsuitable environmental condition for the growth of plants can be an affected factor in this research problem. Qaderi, et al (2019) state that local weather can give impact on plant survival and productivity.

The research is done during the dry season. The high intensity of sunlight heat could disturb the plant growth. Instead, Lestari et, al (2017) found that Mol from vegetables did not affect the height and wet weight of Brassica juncea $\mathrm{L}$ due to the condition of the research field during the rainy season. The plants need suitable conditions to support the growth.

The other factor thought could be the Mol concentration. Pane and Mawarzi (2020) found that Mol from papaya did not affect the height and number of leaves of Lactuca sativa due to low dose of Mol. The concentration $15 \%$ gives the significant effect on plants but only in some parameters. The increase of concentration of Mol Chinese cabbage and cabbage thought could give the maximal effect on the plant.

\section{Conclusion}

Mol of Chinese cabbage and cabbage can be organic fertilizer for Ipomea reptans Poir. The best treatment is P3 with $15 \%$ concentration of Mol. It has significant effect on soil $\mathrm{pH}$, dry weight and shoot dry weight of Ipomea reptans Poir.

\section{References}

Firdaus, F., Purwanto, B, F, \& Salundik. (2014). Dosis Penggunaan Mikroorganisme Lokal (MOL) Ragi Tempe dan Isi Rumen untuk Pengomposan. Jurnal Ilmu Produksi dan Teknologi Hasil Peternakan, 2 (1), 257-261.

Jumriani, K., Patang., Mustarin, A. (2017). Pengaruh Pemberian MOL 
terhadap Pertumbuhan dan Produksi Tanaman Kangkung Darat (Ipomea reptans Poir). Jurnal Pendidikan Teknologi Pertanian, 3 (1), 19-29.

Kusmanto, H., Darmawan, R., Kisnaria, B., \& Setiyadi, Y, B. (2019). Realisasi Literasi Lingkungan Melalui Workshop Mikro Organisme Lokal (MOL). Buletin KKNDik, 1 (1), 1-9.

Lestari, S, U., Susi, N., Mutryarny, E. (2017). Pengujian Mikroorganisme Lokal (MOL) Limbah Sayuran terhadap Pertumbuhan dan Produksi Tanaman Sawi (Brassica juncea L). Jurnal Ilmiah Pertanian 14 (1), 50-60

Lin, W., Lin, M., Zhou, H., Li, Z., \& Lin, W. (2019). The effects of chemical and organic fertilizer usage on rhizosphere soil in tea orchards. Plos One Journal, 14 (5), 1-16.

Mursalim, I., Mustamin, M, K, \& Ali, A.(2018). Pengaruh Penggunaan Pupuk Organik Mikroorganisme Lokal Media Nasi, Batang Pisang, dan Ikan Tongkol Terhadap Pertumbuhan Tanaman Sawi (Brassica juncea). Jurnal Biotek, 6 (1), 32-47.

Pane, E., \& Mawarzi, M. (2020). Trials of Local Microorganism Composition (Mol) Toward Growth and Production Plant Lettuce (Lactuca Sativa). Budapest International Research in Exact Sciences (BirEx) Journal. 2 (1), 44-51.

Priambodo, S, R., Susila, K, D., \& Soniari, N, N. (2019). Pengaruh Pupuk Hayati dan Pupuk Anorganik Terhadap Beberapa Sifat Kimia Tanah Serta Hasil Tanaman Bayam Cabut (Amaranthus tricolor) di Tanah Inceptisol Desa Pedungan. EJurnal Agroekoteknologi Tropika, 8(1), 149-160.
Purbajanti, E, D., Slamet, W., Fuskhah, E., \& Rosyida. (2019). Effects of organic and inorganic fertilizers on growth, activity of nitrate reductase and chlorophyll contents of peanuts (Arachis hypogaea L.). IOP Conf. Series: Earth and Environmental Science, 250 (1), 1-8

Qaderi, M, M., Martel A, B., \& Dixon, S, L. (2019). Environmental Factors Inflfluence Plant Vascular System and Water Regulation. Plants Journal, 8 (65), 1-23.

Suswandi, \& Suharto, I., (2011). Pembelajaran Penerapan Sri ( system of rice intensification) di Lahan Tadah Hujan di Kabupaten Boyolali. Surakarta: Lsk bina bakat dan VECO Indonesia.

Suwatanti, EPS., \& Widiyaningrum, P. (2017). Pemanfaatan MOL Limbah Sayur pada Proses Pembuatan Kompos. Jurnal MIPA, 40 (1), 1-6. Syafruddin, D., Awang, I, S., Ege, B., Bustami, Y., \& Wahyuni, R. (2019). Utilization Of Liquid Organic Fertilizer From Local Microorganism Of Vegetables To The Productivity Of Cayenne Pepper Plant. International Journal of Scientific \& Technology Research, 8 (7), 258-262.

Widha, F, A., Budiyanto, S., \& Purbajanti, E, D. (2018). Pengaruh lama pemeraman dan dosis pupuk organik cair berbasis mol sayur dan buah terhadap pertumbuhan dan produksi tomat ceri (Solanum lycopersicum var. cerasiforme). J. Agro Complex 2(2), 162-168.

Widjajanto, D., Purbajanti, E, D., Sumarsono., \& Utama, C,S (2017). The Role of Local Microorganisms Generated from Rotten Fruits and Vegetables in Producing Liquid Organic Fertilizer. Journal of 
Applied Chemical Science, 4 (1), 325-329

Yuliana, M., Meryandini, A., \& Sunarti, T, C. (2019). Seleksi Bakteri Asam Laktat dan Pemanfaatannya sebagai Starter pada Fermentasi Biji Sorgum. Jurnal Sumberdaya HAYATI, 5 (1), 35-42.
Zulputra., \& Hidayat, T., (2018). Respon Tanaman Kacang Panjang (Vigna sinensi L.) terhadap Pemberian Pupuk Organik Cair Mikroorganisme Lokal Buah Mangga. Jurnal Sungkai, 6 (1), 5059. 